Article

\title{
Operational Characteristics of Immobilized Ochrobactrum sp. CUST210-1 Biosystem and Immobilized Chromate Reductase Biosystem in Continuously Treating Actual Chromium-Containing Wastewater
}

\author{
Guey-Horng Wang ${ }^{1}$, Teh-Hua Tsai ${ }^{2}$, Ching-Hung Chiu ${ }^{3}$, Chiu-Yu Cheng ${ }^{3}$ \\ and Ying-Chien Chung ${ }^{3, *}$ (D) \\ 1 Research Center of Natural Cosmeceuticals Engineering, Xiamen Medical College, Xiamen 361008, China; \\ wanggh@livemail.tw \\ 2 Department of Chemical Engineering and Biotechnology, National Taipei University of Technology, \\ Taipei 10608, Taiwan; thtsai@ntut.edu.tw \\ 3 Department of Biological Science and Technology, China University of Science and Technology, \\ Taipei 11581, Taiwan; chiuchinghung3@gmail.com (C.-H.C.); cycheng@cc.cust.edu.tw (C.-Y.C.) \\ * Correspondence: ycchung@cc.cust.edu.tw; Tel.: +886-2278-1862; Fax: +886-2786-5456
}

Received: 19 July 2020; Accepted: 25 August 2020; Published: 27 August 2020

\begin{abstract}
Cr}(\mathrm{VI})$ detoxification by biotreatment is considered one of the most practical detoxification methods, especially at low-to-medium concentrations. Although the capabilities of chromium-reducing bacteria and related enzymes in removing $\mathrm{Cr}(\mathrm{VI})$ have been explored, little is known about their differences in engineering applications. In this study, Ochrobactrum sp. CUST210-1 was isolated and its chromate reductase identified and separated as biological elements in biosystems developed for $\mathrm{Cr}(\mathrm{VI})$ removal. Results indicate that intracellular $\mathrm{Cr}(\mathrm{OH})_{3(\mathrm{~s})}$ accounted for $88.01 \%$ of $\mathrm{Cr}(\mathrm{VI})$ reduction product, and a possible reduction mechanism was exposed. The chromate reductase in Ochrobactrum sp. CUST210-1 was ChrR protein, and its crystal structure was revealed. The toxicity of $\mathrm{Cr}(\mathrm{VI})$-containing wastewater was decreased by $57.8 \%$ and $67.0 \%$ (at minimum) by the CUST210-1 strain and ChrR, respectively. The Ochrobactrum sp. CUST210-1 biosystem demonstrated good adaptability to $\mathrm{pH}(7-9)$, and the ChrR biosystem exhibited high removal efficiency $(>98.2 \%)$ at a wide range of temperatures $\left(25^{\circ} \mathrm{C}-40{ }^{\circ} \mathrm{C}\right)$. The outlet $\mathrm{Cr}(\mathrm{VI})$ concentration of the CUST210-1 biosystem met the industrial discharge limit of $0.5 \mathrm{mg} \mathrm{L}^{-1}$ when the inlet $\mathrm{Cr}(\mathrm{VI})$ concentration in the actual $\mathrm{Cr}(\mathrm{VI})$-containing wastewater was $<430 \mathrm{mg} \mathrm{L}^{-1}$. The stricter water quality standard of $0.05 \mathrm{mg} \mathrm{L}^{-1}$ could be complied with by the immobilized ChrR biosystem when $<150 \mathrm{mg} \mathrm{L}^{-1} \mathrm{Cr}$ (VI) concentration was introduced. These developed biosystems can be used in the bioremediation of various $\mathrm{Cr}(\mathrm{VI})$-contaminated wastewaters. Regarding capital costs, those of the CUST210-1 biosystem were higher. To our knowledge, this is the first report comparing differences in the economic and operational characteristics of bacteria and enzyme biosystems for $\mathrm{Cr}(\mathrm{VI})$ removal.
\end{abstract}

Keywords: bioremediation; chromium-reducing bacteria; chromate reductase; hexavalent chromium

\section{Introduction}

In the environment, the two most stable oxidation states of chromium are its hexavalent $(\mathrm{Cr}(\mathrm{VI}))$ and trivalent $(\mathrm{Cr}(\mathrm{III}))$ forms [1]. $\mathrm{Cr}(\mathrm{III})$ is considered less toxic than $\mathrm{Cr}(\mathrm{VI})$, because it is conventionally considered an essential micronutrient in animal and human diets. By contrast, $\mathrm{Cr}(\mathrm{VI})$ is highly toxic, mutagenic, carcinogenic, and teratogenic to biological systems and is readily taken up by 
organisms via the sulfate transport system [2]; hence, most regulatory agencies worldwide consider $\mathrm{Cr}(\mathrm{VI})$ a priority pollutant $[3,4]$. Chromium compounds are used in chromium electroplating, metal processing, leather tanning, metal corrosion inhibition, papermaking, pigment manufacturing, and other industrial applications [5]. Cr(VI)-containing industrial effluents without proper treatment are released, intentionally or accidentally, into environments in developing and underdeveloped countries [6]; thus, the contamination of surface waters and groundwaters with $\mathrm{Cr}(\mathrm{VI})$ is a potential concern. Concentrations of $\mathrm{Cr}(\mathrm{VI})$ in these effluents must be reduced to permissible limits by using the appropriate technology before the effluents are discharged into the environment. The Environmental Protection Agency in Taiwan has set the maximum contaminant levels for $\mathrm{Cr}(\mathrm{VI})$ in most industrial effluents at $0.5 \mathrm{mg} \mathrm{L}^{-1}$ and for fisheries water, drinking water, groundwater, and surface water at $0.05 \mathrm{mg} \mathrm{L}^{-1}$.

Many physical and chemical methods have been developed for $\mathrm{Cr}(\mathrm{VI})$ removal, such as precipitation, adsorption, ion exchange, electrochemical treatment, evaporation, and reverse osmosis [5]. Nevertheless, existing methods are inefficient and not economically feasible, especially when $\mathrm{Cr}(\mathrm{VI})$ contamination in wastewater must be reduced to a low level to meet strict environmental standards, such as $0.5 \mathrm{mg} \mathrm{L}^{-1}$ [7]. Several researchers have reported that the biological detoxification of $\mathrm{Cr}(\mathrm{VI})$ by bacteria and their enzymes is considered one of the most practical removal methods, especially at low-to-medium concentrations of $\mathrm{Cr}(\mathrm{VI})$, due to its ecological compatibility and low cost $[4,8]$.

Bacteria endowed with the capacity to reduce $\mathrm{Cr}(\mathrm{VI})$ levels are termed chromium-reducing bacteria (CRB) [9]. Numerous varieties of CRB reduce $\mathrm{Cr}(\mathrm{VI})$ to $\mathrm{Cr}(\mathrm{III})$, including Bacillus cereus [10], Ochrobactrum sp. [11], Paenibacillus ferrarius [12], Exiguobacterium aestuarii [13], Shewanella sp., Desulfovibrio sp., Enterobacter sp., Micrococcus sp., Pseudomonas sp. [8], and several other species [5]. Although most of these CRB have been isolated from various $\mathrm{Cr}(\mathrm{VI})$-contaminated sites, the availability of $\mathrm{CRB}$ is an essential prerequisite to meeting strict environmental standards, regardless of their removal efficiency or capacity. Thus, the feasibility of chromate reductase in removing $\mathrm{Cr}(\mathrm{VI})$ is considered, because it functions without the requirement of high organics concentration and complicated biochemistry processes like bacterial cells but possesses a high substrate specificity for $\mathrm{Cr}(\mathrm{VI})$ reduction.

$\mathrm{Cr}(\mathrm{VI})$ reduction or detoxification by CRB is regarded as an enzyme catalysis reaction attributed to soluble chromate reductase or cell membrane-bound chromate reductase [14]. Cell immobilization techniques are typically employed in wastewater treatments, because they result in a solid-liquid separation that is more stable, and thus, the products are easier to reuse [15]. Similarly, the use of immobilized enzymes instead of living bacterial cells may overcome the limit of the toxicity of $\mathrm{Cr}(\mathrm{VI})$ to the chromate reductase and produce dilute $\mathrm{Cr}(\mathrm{VI})$ residue, in addition to achieving the aforementioned advantages [16]. Chromate reductase is divided into four categories: (1) cytochrome C, (2) flavin protein, (3) old yellow enzymes, and (4) hydrogenases [7]. Among chromate reductase enzymes, soluble chromate reductase such as ChrR, nfsA, and yieF are suitable for development as biocatalysts for $\mathrm{Cr}(\mathrm{VI})$ bioremediation, because they are more amenable to protein engineering to suit the environmental conditions of contaminated sites [14]. To date, soluble chromate reductase resulting from Pseudomonas putida, Escherichia coli, Shewanella sp., Gluconacetobacter sp., and Stenotrophomonas maltophilia have been identified and their basic characteristics enumerated [14].

Although the basic capabilities of CRB and related enzymes in removing $\mathrm{Cr}(\mathrm{VI})$ have been examined, little is known about their differences in engineering applications, such as operating conditions, operating guidelines, applicable targets, and cost analysis. In this study, immobilized Ochrobactrum sp. CUST210-1 and immobilized enzyme biosystems were applied to remove $\mathrm{Cr}(\mathrm{VI})$ from actual wastewater to compare their operational characteristics in a continuous-flow mode. The results can provide insight into strategies for removing $\mathrm{Cr}(\mathrm{VI})$ from various environments. 


\section{Materials and Methods}

\subsection{Materials}

The Ochrobactrum sp. CUST210-1 was isolated from soil in the vicinity of an electroplating factory (Changhua County, Taiwan) using the spread plate method and then cultivated in Luria-Bertani (LB) broth supplemented with $\mathrm{Na}_{2} \mathrm{Cr}_{2} \mathrm{O}_{7}$ (Li-Hsin chemical company, Hsinchu City, Taiwan) ((final concentration: $300 \mathrm{mg} \mathrm{L}^{-1} \mathrm{Cr}(\mathrm{VI})$ ) in 300-mL Erlenmeyer flasks on a rotary shaker (Sunway scientific company, Taipei City, Taiwan) $(250 \mathrm{rpm})$ at $35^{\circ} \mathrm{C}$ under aerobic conditions. To identify the $\mathrm{Cr}(\mathrm{VI})$-reducing bacterium, the cells were lysed, and the DNA was extracted. The 16S rRNA gene sequence of the isolate was compared with the NCBI database using BLASTN, and the closest match to the bacterial isolate was retrieved.

To evaluate the toxicity of $\mathrm{Cr}(\mathrm{VI})$-containing wastewater before and after treatment, a Microtox toxicity assay system (Model 500; Azur Environmental, Newark, DE, USA) comprising Vibrio fischeri and a fish poison test using Pseudorasbora parva obtained from a lake in New Taipei City, Taiwan were used $[17,18]$. The synthetic wastewater used for toxicity evaluation contained 1/1000 LB supplemented with a final $\mathrm{Cr}(\mathrm{VI})$ concentration of $300 \mathrm{mg} \mathrm{L}^{-1}$. All analytic chemicals used in the experiment were of an analytical grade.

\subsection{Distribution of Chromium (VI) Reduction Products}

The Ochrobactrum sp. CUST210-1 was cultivated in LB supplemented with 300-mg L $\mathrm{L}^{-1} \mathrm{Cr}(\mathrm{VI})$ at $35^{\circ} \mathrm{C}$ under aerobic conditions. The shaking velocity and the $\mathrm{pH}$ of the culture were set at $150 \mathrm{rpm}$ and 7.0, respectively. The $\mathrm{pH}$ of the culture was adjusted by the addition of $0.1-\mathrm{N} \mathrm{HCl}$ or $\mathrm{NaOH}$ to the culture. After $24 \mathrm{~h}$ of cultivation, $200 \mathrm{~mL}$ of culture solution containing the CUST210-1 strain was centrifuged at $6000 \mathrm{rpm}$ for $10 \mathrm{~min}$, and the bacterial pellets were obtained. The sequential extraction procedure was then used to analyze the distribution of $\mathrm{Cr}(\mathrm{VI})$ reduction products $[19,20]$. The bacterial pellets were sequentially extracted with $1-\mathrm{M} \mathrm{MgCl}_{2} ; 0.5-\mathrm{M} \mathrm{KF}$; $1-\mathrm{M} \mathrm{NaAc}$; and a mixture of $0.02-\mathrm{M}$ $\mathrm{HNO}_{3}, 30 \% \mathrm{H}_{2} \mathrm{O}_{2}$, and 3.2-M NH 4 Ac to fractionate the $\mathrm{Cr}$ (III) compounds into exchangeable/loosely, adsorbed, carbonate, and organically bound forms, respectively. Finally, the residue was acidified with 16- $\mathrm{M} \mathrm{HNO}_{3}$ until the dark color disappeared. After centrifugation, $\mathrm{Cr}(\mathrm{OH})_{3}$ was obtained. To assess the intracellular $\mathrm{Cr}(\mathrm{OH})_{3}$, the bacterial pellets were placed in 20-mM phosphate buffer (PB), vibrated at $4{ }^{\circ} \mathrm{C}$ by an ultrasonic processor (UP-100, ChromTech, Apple Valley, MN, USA), and centrifuged at $12,000 \mathrm{rpm}$ for $20 \mathrm{~min}$ at $4{ }^{\circ} \mathrm{C}$. The precipitate was acidified with $16-\mathrm{M} \mathrm{HNO}_{3}$ until the dark color disappeared.

\subsection{Separation and Purification of Chromate Reductase}

After incubating the CUST210- 1 strain at $35^{\circ} \mathrm{C}$ for $24 \mathrm{~h}$, the cells were collected by centrifugation at $8000 \mathrm{rpm}$ for $15 \mathrm{~min}$. The bacterial pellets were washed with $20-\mathrm{mM} \mathrm{PB}$, and the suspension was placed in PB solution for vibration at $4{ }^{\circ} \mathrm{C}$ by the ultrasonic processor $(20 \mathrm{kHz}, 130$ watt). Then, the suspension was centrifuged at $12,000 \mathrm{rpm}$ for $20 \mathrm{~min}$ at $4{ }^{\circ} \mathrm{C}$, and the supernatant was collected for further enzyme purification. To purify the chromate reductase, the supernatant was mixed with $20-\mathrm{mM}$ PB; the active components were separated using a HiPrep Q XL 16/10 column (16 mm $\times 100 \mathrm{~mm}$,

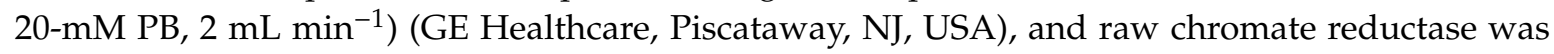
collected using a HiTrap Phenyl Sepharose column $(7 \mathrm{~mm} \times 25 \mathrm{~mm}, 50$-mM sodium phosphate and 1.0-M ammonium sulphate, $1 \mathrm{~mL} \mathrm{~min}^{-1}$ ) (GE Healthcare) and then purified using a Mono Q HR 5/5 column $\left(5 \mathrm{~mm} \times 50 \mathrm{~mm}, 20-\mathrm{mM}\right.$ Bis-Tris, $\left.0.5 \mathrm{~mL} \mathrm{~min}^{-1}\right)$ (GE Healthcare).

To analyze the molecular weight of the chromate reductase, SDS-PAGE was performed on $10 \%$ gels, as described by Laemmli [21]. To determine the crystal structure of the chromate reductase, the purified protein was dissolved in Tris- $\mathrm{HCl}$ and $\mathrm{NaCl}(10$ and $150 \mathrm{mM}$, respectively, $\mathrm{pH} 8.0)$ and crystallized using the sitting drop vapor diffusion method, with a PEG8000 (10\%), $\mathrm{NaCl}(50 \mathrm{mM})$, and calcium acetate $(100 \mathrm{mM})$ solution as the precipitant. X-ray diffraction data of the crystals were 
collected at a resolution of $2.2 \AA$ (Instrumentation Center, National Taiwan University, Taiwan), and the structure was solved through the molecular replacement method [22]. Homology searches were performed using BLASTP.

\subsection{Analysis of Genes Involved in the Cr(VI) Reduction}

To identify the functional genes involved in the $\mathrm{Cr}(\mathrm{VI})$ reduction, known chromate reductase genes were used as a reference. The genes included $a p c A, n f s A, n f s B, y i e F, a z r, c r S, m r e G, h y d C, m t r C, o m c A$, and $c h r R$ [8]. Their primer pairs were used (Table 1), and gene amplification was performed to synthesize corresponding chromate reductase genes from the strain by using a Bio Rad C1000 thermocycler (Bio Rad, Hercules, CA, USA), as previously described [22-30]. The operating conditions for polymerase chain reactions and 454 pyrosequencing followed those of De Silva et al. [31]. The synthesized genes from the CUST210-1 strain were sequenced and their sequences compared with other chromate reductase genes in GenBank.

Table 1. Oligonucleotide primer pairs used to amplify the chromate reductase gene.

\begin{tabular}{|c|c|}
\hline Targeted Gene & Sequence Primers $\left(5^{\prime}-3^{\prime}\right)$ \\
\hline$a p c A$ & $\begin{array}{l}\text { F ATGAGTATCGTCACTAAATCCATCG } \\
\text { R TACTGCATTGCACCGACAAC }\end{array}$ \\
\hline$n f_{S} A$ & $\begin{array}{l}\text { F ATCGAATTCAGACTGAAGGCTCACTTTGC } \\
\text { R ATCGCGGATCCACGTAACGCTTTGTCGGT }\end{array}$ \\
\hline$n f_{s} B$ & $\begin{array}{l}\text { F GTAGGATCCGATATCATTTCTGTCGC } \\
\text { R ACTGAATTCTTACACTTCGGTTAAGGTG }\end{array}$ \\
\hline yieF & $\begin{array}{l}\text { F AGCTCATTTAATGGCATGG } \\
\text { R ATCAAGGGAATGTCGGCAA }\end{array}$ \\
\hline$a z r$ & $\begin{array}{l}\text { F AATACGGTAAGCGCAGCG } \\
\text { R ATTATGTAAACCTATTTG }\end{array}$ \\
\hline$c r S$ & $\begin{array}{l}\text { F CATATGGCCTTGCTCTTCACCCCCCTGGAACTC } \\
\text { R GAATTCCTAAAACCСCCT } \\
\text { TTGGTACTGGGGGGGTAC }\end{array}$ \\
\hline mreG & $\begin{array}{l}\text { F ATCACTTCGGAACTGGGTGT } \\
\text { R TACCCCGCAACACACTGTAA }\end{array}$ \\
\hline hydC & $\begin{array}{l}\text { F CCTCTTTATCTTTAACAAAGGGTGCAGGGE } \\
\text { R GGGTGCAGGGTTCAGCGAGCCTCTTTTTGGG }\end{array}$ \\
\hline$m t r C$ & $\begin{array}{l}\text { F AGATCTGTTGGCGCTAGAGCATAG } \\
\text { R GCGGCCGCTAATAGGCTTCCCAATTTGT }\end{array}$ \\
\hline omcA & $\begin{array}{l}\text { F AGCCGTATGATAGTGGGCTG } \\
\text { R TCACTGAGACGAATACGGCG }\end{array}$ \\
\hline $\operatorname{chr} R$ & $\begin{array}{l}\text { F ATGTCTGATACGTTGAAAGTTGTTA } \\
\text { R CAGGCCTTCACCCGCTTA }\end{array}$ \\
\hline
\end{tabular}

\subsection{Toxicity Evaluation of $\mathrm{Cr}(V I)$ Reduction Products in Batch Treatment}

To evaluate the change in its toxicity after treatment, 300- $\mathrm{mg} \mathrm{L}^{-1} \mathrm{Cr}(\mathrm{VI})$-containing wastewater was treated by the CUST210-1 strain or chromate reductase in batch mode. The initial concentrations of the CUST210-1 strain and the enzymatic activity were $3 \times 10^{7} \mathrm{cfu} \mathrm{mL}^{-1}$ and $10.8 \mathrm{U} \mathrm{mg-protein}{ }^{-1}$, respectively. The treatment time for the CUST210-1 strain and chromate reductase was set for $2 \mathrm{~h}$ and $0.5 \mathrm{~h}$, respectively. Toxicity was evaluated using $V$. fischeri and P. parva, and toxicity units are expressed as $\mathrm{EC}_{50}$ and $\mathrm{LC}_{50}$. The analysis data were evaluated using a Probit analysis in IBM SPSS, version 20 (IBM Corp, Armonk, NY, USA). 


\subsection{Apparatus for Continuous Cr(VI) Removal}

A cylindrical packed-bed bioreactor (CPB; length $25 \mathrm{~cm}$, id $16 \mathrm{~cm}$ ) was constructed from acrylic materials for the immobilized Ochrobactrum sp. CUST210-1 biosystem (Figure 1A). Three sampling pores were constructed at the top of the biosystem through which the $\mathrm{pH}$ value, dissolved oxygen (DO) content, and $\mathrm{Cr}(\mathrm{VI})$ concentration in the wastewater could be measured. Plastic Raschig rings (rosette type, id $2 \mathrm{~cm}$ ) were used as packing material. The inflow solution, which contained 1/1000 LB supplemented with $300 \mathrm{mg} \mathrm{L}^{-1} \mathrm{Cr}(\mathrm{VI})$ and the CUST210-1 strain $\left(3 \times 10^{7} \mathrm{cfu} \mathrm{mL}^{-1}\right)$ stored in the reservoir, was continuously recirculated with the flow directed upward from the inlet at the bottom of the reactor. The liquid retention time (LRT) of the inflow solution was controlled at $12 \mathrm{~h}$. When the outlet $\mathrm{Cr}(\mathrm{VI})$ concentration was less than $0.5 \mathrm{mg} \mathrm{L}^{-1}$, the cell immobilization procedure was regarded as completed.

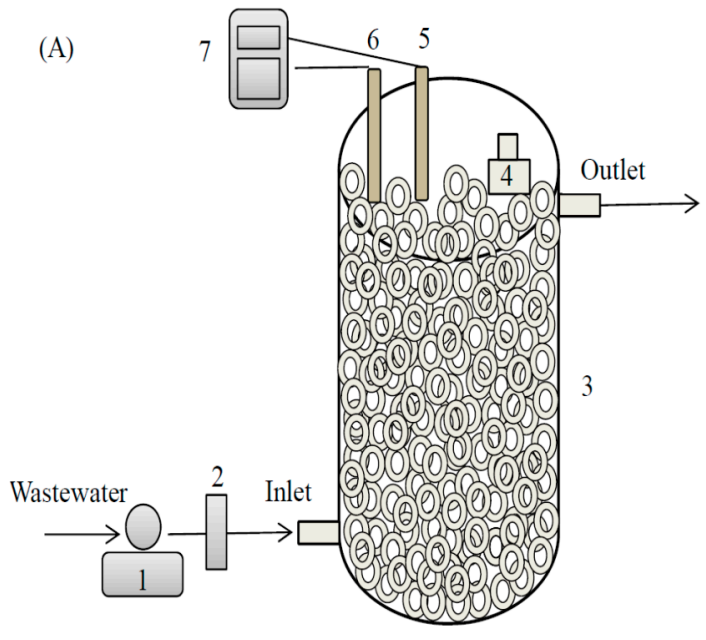

(A)

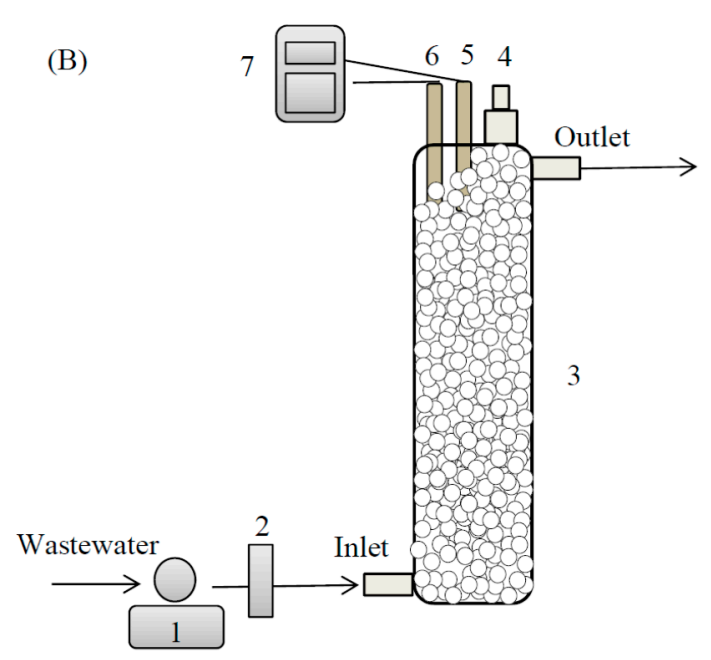

(B)

Figure 1. Schematic of (A) immobilized Ochrobactrum sp. CUST210-1 biosystem and (B) immobilized enzyme biosystem: (1) peristaltic pump, (2) flow meter, (3) bioreactor, (4) sampling port, (5) pH electrode, (6) Dissolved oxygen (DO) electrode, and (7) digital pH/DO meter.

Calcium alginate beads are made through external gel formation [32]. Three percent $(w / v)$ sodium alginate in 50-mM sodium PB ( $\mathrm{pH} 7.0$ ) was mixed with 5\% chromate reductase solution at the ratio of 1:1. The mixture was taken into a syringe and dripped directly into a gently stirred $1.5 \% \mathrm{CaCl}_{2}$ solution from a height of approximately $2 \mathrm{~cm}$; this resulted in the formation of spherical beads of enzyme-entrapped calcium alginate. The beads were left in the $\mathrm{CaCl}_{2}$ solution for $30 \mathrm{~min}$, recovered by filtration, and thoroughly washed with distilled water thrice. Toxicity evaluation of the $\mathrm{Cr}(\mathrm{VI})$ reduction products was conducted using the immobilized chromate reductase beads in batch mode. The beads were packed into a cylindrical column bioreactor (CCB) until the immobilized enzyme biosystem was used for continuous $\mathrm{Cr}(\mathrm{VI})$ removal. The CCB (length $32 \mathrm{~cm}$, id $8 \mathrm{~cm}$ ) was constructed from acrylic materials, with sampling pores installed as in the Ochrobactrum sp. CUST210-1 biosystem (Figure 1B).

\subsection{Effects of Operating Parameters on Continuous Cr(VI) Removal by Immobilized Ochrobactrum sp. CUST210-1 Biosystem}

When the Ochrobactrum sp. CUST210-1 biosystem completed immobilization, synthetic wastewater was continuously introduced to the CPB. The effects of different operating parameters, including LRT (1-6 h), pH (7-9), operating temperature $\left(25^{\circ} \mathrm{C}-45^{\circ} \mathrm{C}\right)$, and $\mathrm{Cr}(\mathrm{VI})$ concentration $\left(50-400 \mathrm{mg} \mathrm{L}^{-1}\right)$, on continuous $\mathrm{Cr}(\mathrm{VI})$ removal were assessed, and the synthetic wastewater (1/1000 LB supplemented 
with $\mathrm{Cr}(\mathrm{VI}))$ was used in this study. The designed LB concentration simulated organic concentrations in tannery wastewater after treatment by chemical precipitation. Generally, the inflow $\mathrm{Cr}(\mathrm{VI})$ concentration, $\mathrm{pH}, \mathrm{LRT}$, and operating temperature were set as $200 \mathrm{mg} \mathrm{L}^{-1}, 7.0,4 \mathrm{~h}$, and $35{ }^{\circ} \mathrm{C}$, respectively. Each operating parameter was continuously operated for at least $6 \mathrm{~h}$, with the results expressed as the average for each parameter.

Furthermore, the effects of the actual $\mathrm{Cr}(\mathrm{VI})$-containing wastewater, which was collected from the effluent of tannery wastewater after treatment by chemical precipitation (New Taipei City, Taiwan), on $\mathrm{Cr}(\mathrm{VI})$ removal were evaluated by continuously feeding the water into the biosystem for 196 days. In the case of this actual wastewater, the LRT, operating temperature, and $\mathrm{pH}$ were controlled at $4 \mathrm{~h}$, $35^{\circ} \mathrm{C}$, and 7.0.

\subsection{Effects of Operating Parameters on Continuous Cr(VI) Removal by Immobilized Enzyme Biosystem}

The effects of various operating parameters, including the LRT $(0.5-3 \mathrm{~h})$, operating temperature $\left(25{ }^{\circ} \mathrm{C}-45^{\circ} \mathrm{C}\right), \mathrm{Cr}(\mathrm{VI})$ concentration $\left(25-150 \mathrm{mg} \mathrm{L}^{-1}\right)$, and life cycle of the immobilized bead, on continuous $\mathrm{Cr}(\mathrm{VI})$ removal by the immobilized enzyme biosystem were assessed with regard to the synthetic wastewater $(1 / 10,000 \mathrm{LB}$ supplemented with $\mathrm{Cr}(\mathrm{VI}))$. The designed LB concentration simulated the organic concentration in electroplating wastewater after treatment by chemical precipitation. The initial enzyme activity, inflow $\mathrm{Cr}(\mathrm{VI})$ concentration, $\mathrm{LRT}, \mathrm{pH}$, and operating temperature were 10.2 $\mathrm{U}$ mg-protein ${ }^{-1}, 100 \mathrm{mg} \mathrm{L}^{-1}, 1 \mathrm{~h}, 7$, and $35^{\circ} \mathrm{C}$, respectively, unless otherwise stated. Each parameter was continuously operated for at least $6 \mathrm{~h}$, with results expressed as the average for each. Furthermore, the effects of actual $\mathrm{Cr}(\mathrm{VI})$-containing wastewater, derived from the effluent of electroplating wastewater after treatment by chemical precipitation (Changhua County, Taiwan), on continuous $\mathrm{Cr}(\mathrm{VI})$ removal were evaluated by feeding the water into the biosystem for 196 days. In this case, the LRT, operating temperature, and $\mathrm{pH}$ were controlled at $1 \mathrm{~h}, 35^{\circ} \mathrm{C}$, and 7.0, respectively. The influent $\mathrm{pH}$ was adjusted to the desired working $\mathrm{pH}$ level by the addition of $1-\mathrm{N} \mathrm{HCl}$ or $\mathrm{NaOH}$.

\subsection{Analysis}

$\mathrm{Na}_{2} \mathrm{Cr}_{2} \mathrm{O}_{7}$ of special-grade chemicals was dried at $200{ }^{\circ} \mathrm{C}$ for $1 \mathrm{~h}$ and left in a desiccator. Subsequently, $100.8 \mathrm{mg}$ of $\mathrm{Na}_{2} \mathrm{Cr}_{2} \mathrm{O}_{7}$ was weighed, dissolved in water, and diluted to $100 \mathrm{~mL}$. The diluted solution was used as a standard stock solution of $400-\mathrm{mg} \mathrm{L}^{-1} \mathrm{Cr}(\mathrm{VI})$. The colorimetric method (1,5-diphenylcarbazide method) for $\mathrm{Cr}(\mathrm{VI})$ measurement was used as described previously [11]. The concentrations of collected extracts for various forms of $\mathrm{Cr}$ species and total $\mathrm{Cr}$ were analyzed using an atomic absorption spectrophotometer (Hitachi, Tokyo, Japan). DO and $\mathrm{pH}$ values were continuously determined by an online DO and pH meter (Hanna Instruments, Woonsocket, RI, USA). For Biochemical oxygen demand (BOD) analysis, the standard method 5210B was adopted. Chemical oxygen demand (COD) was analyzed using a Hach DR2800 portable spectrophotometer (Hach, Loveland, CO, USA). For toxicity evaluation, the inhibition reaction of bioluminescence of $V$. fischeri exposed to tested solutions for $15 \mathrm{~min}$ was analyzed, and the acute toxic reaction of $P$. parva exposed to the solutions for $96 \mathrm{~h}$ was analyzed.

\section{Results and Discussion}

\subsection{Distribution of Cr(VI) Reduction Products and Possible Cr(VI) Reduction Mechanism}

Knowledge of the state, form, and location of Cr(VI) treated by Ochrobactrum sp. CUST210-1, such as adsorption state, complex formation, or precipitate form, is essential for the development of a suitable remediation process. In addition, the characterization of the product is helpful for understanding the reduction mechanism of $\mathrm{Cr}(\mathrm{VI})$ by Ochrobactrum sp. CUST210-1. Table 2 lists the distribution of various chromium species inside and outside the cells after the batch treatment. A small amount (3.05\%) of $\mathrm{CrO}_{4}{ }^{2-}$ or $\mathrm{Cr}_{2} \mathrm{O}_{7}{ }^{2-}$ was adsorbed on the positively charged functional group of the cell wall, $8.49 \%$ as the $\mathrm{Cr}(\mathrm{III})$ form was coordinated with negatively charged functional groups such as carbonyl or amide 
groups, and $3.12 \%$ as the $\mathrm{Cr}$ (III) form existed in the solution as a free form; however, most of the $\mathrm{Cr}(\mathrm{VI})$ was deposited, inside or outside of the cells, as the $\mathrm{Cr}(\mathrm{OH})_{3}$ form during the $\mathrm{Cr}(\mathrm{VI})$ reduction due to $\mathrm{Cr}$ (III) tending to form precipitates at $\mathrm{pH}>5$ [4]. Table 3 lists the $\mathrm{Cr}$ (III) distribution in $\mathrm{Cr}$ (III) species of $\mathrm{Cr}(\mathrm{VI})$ reduction products after the batch treatment. The results indicate that the exchangeable form of $\mathrm{Cr}(\mathrm{III})$, adsorbed $\mathrm{Cr}(\mathrm{III})$, organically bound $\mathrm{Cr}(\mathrm{III})$, and carbonate-bound $\mathrm{Cr}$ (III) on the cell surface accounted for $0.21 \%, 2.90 \%, 5.53 \%$, and $0.13 \%$, respectively. $\mathrm{Cr}(\mathrm{OH})_{3}$ precipitate accounted for $88.01 \%$. In brief, $\mathrm{Cr}(\mathrm{VI})$ compounds were usually adsorbed by the cell surface, and $\mathrm{Cr}(\mathrm{III})$ may exist in the form of organic-Cr(III) complexes or in the precipitate form of $\mathrm{Cr}(\mathrm{OH})_{3(\mathrm{ss})}$. We speculate that few complex salts occurred in the form of $\mathrm{Cr}(\mathrm{OH})_{4}{ }^{-}, \mathrm{Cr}_{2} \mathrm{O}_{2}(\mathrm{OH})_{4}{ }^{2-}$, or $\mathrm{Cr}_{3} \mathrm{O}_{4}(\mathrm{OH})_{4}{ }^{3-}$ in the solution. Moreover, most $\mathrm{Cr}(\mathrm{OH})_{3(\mathrm{~s})}$ was located inside cells, which was similar to results reported for $\mathrm{Cr}(\mathrm{VI})$ reduction by Bacillus amyloliquefaciens, Synechocystis sp., Cellulosimicrobium funkei, and P. aeruginosa [33-36] but different from studies identifying extracellular deposits by Ochrobactrum anthropi, Vigribacillus sp., and Shewanella oneidensis [37-39].

Table 2. Distribution of chromium (VI) reduction products.

\begin{tabular}{cccccccc}
\hline $\begin{array}{c}\mathrm{Cr} \\
\text { Distribution }\end{array}$ & $\begin{array}{c}\mathrm{Cr}(\mathrm{VI}) \text { by Surface } \\
\text { Adsorption }\end{array}$ & $\begin{array}{c}\mathrm{Cr}(\mathrm{III}) \text { by Surface } \\
\text { Adsorption }\end{array}$ & $\begin{array}{c}\mathrm{Cr}(\mathrm{III}) \text { in } \\
\text { Solution }\end{array}$ & $\begin{array}{c}\mathrm{Cr}(\mathrm{VI}) \text { in } \\
\text { Solution }\end{array}$ & $\begin{array}{c}\mathrm{Cr}(\mathrm{OH})_{3(\mathrm{~s})} \\
\text { Outside Cell }\end{array}$ & $\begin{array}{c}\mathrm{Cr}(\mathrm{VI}) \\
\text { Inside Cell }\end{array}$ & $\begin{array}{c}\mathrm{Cr}(\mathrm{OH})_{3(\mathrm{~s})} \\
\text { Inside Cell }\end{array}$ \\
\hline $\begin{array}{c}\text { Relative } \\
\text { amount (\%) }\end{array}$ & $3.05 \%$ & $8.49 \%$ & $3.12 \%$ & $0 \%$ & $26.70 \%$ & $0 \%$ & $58.64 \%$ \\
\hline
\end{tabular}

Table 3. Distribution of $\mathrm{Cr}(\mathrm{III})$ species in $\mathrm{Cr}(\mathrm{VI})$ reduction products.

\begin{tabular}{|c|c|c|c|c|c|c|c|}
\hline & $\begin{array}{l}\text { Cr(III) in } \\
\text { Solution }\end{array}$ & $\begin{array}{c}\mathrm{Cr}(\mathrm{III}) \\
\text { Exchangeable Form }\end{array}$ & $\begin{array}{c}\text { Cr(III) } \\
\text { Adsorbed Form }\end{array}$ & $\begin{array}{c}\mathrm{Cr}(\mathrm{III}) \\
\text { Organically Bound }\end{array}$ & $\begin{array}{c}\mathrm{Cr}(\mathrm{III}) \\
\text { Carbonate Form }\end{array}$ & $\begin{array}{c}\mathrm{Cr}(\mathrm{OH})_{3(\mathrm{~s})} \\
\text { Outside Cell }\end{array}$ & $\begin{array}{l}\mathrm{Cr}(\mathrm{OH})_{3(\mathrm{~s})} \\
\text { Inside Cell }\end{array}$ \\
\hline $\begin{array}{l}\text { Relative amount } \\
\text { of Cr(III) } \\
\text { species (\%) }\end{array}$ & $3.22 \%$ & $0.21 \%$ & $2.90 \%$ & $5.53 \%$ & $0.13 \%$ & $27.53 \%$ & $60.48 \%$ \\
\hline
\end{tabular}

On the basis of the product analysis results, the following $\mathrm{Cr}(\mathrm{VI})$ reduction mechanism or $\mathrm{Cr}(\mathrm{VI})$ resistance-tolerance mechanism of Ochrobactrum sp. CUST210-1 may be inferred. (1) Partial Cr(VI) directly binds via electrostatic attraction to positively charged functional groups on the surface of the CUST210-1 strain (3.05\%), or partial Cr(VI) is reduced to $\mathrm{Cr}(\mathrm{III})$ via membrane-associated chromate reductase or soluble chromate reductase (i.e., $\mathrm{ChrR}$ ) and binds to negatively charged functional groups on the surface of the CUST210-1 strain (8.49\%), (2) a portion of $\mathrm{Cr}(\mathrm{VI})$ is reduced to $\mathrm{Cr}(\mathrm{III})$ by $\mathrm{ChrR}$ and (i) remains in the solution as the $\mathrm{Cr}(\mathrm{OH})_{4}{ }^{-}$form or even as the multinuclear polymers $\mathrm{Cr}_{2} \mathrm{O}_{2}(\mathrm{OH})_{4}{ }^{2-}$ or $\mathrm{Cr}_{3} \mathrm{O}_{4}(\mathrm{OH})_{4}{ }^{3-}(3.12 \%)$ or (ii) is mainly formed as $\mathrm{Cr}(\mathrm{OH})_{3(\mathrm{~s})}$ outside the cell $(26.70 \%)$, and (3) most $\mathrm{Cr}(\mathrm{VI})$ species enter the cell via the $\mathrm{SO}_{4}{ }^{2-}$ channels then are reduced to $\mathrm{Cr}$ (III) via intracellular $\mathrm{ChrR}$ and deposited inside the cell as $\mathrm{Cr}(\mathrm{OH})_{3(\mathrm{~s})}(58.64 \%)$. An analogous mechanism has been discovered in other bacteria, such as P. aeruginosa and S. maltophilia [14,36].

\subsection{Enzyme and Genes Involved in the Cr(VI) Reduction}

According to the literature, chromate reductase is divided into the following categories: (1) Cytochrome C: cyt $\mathrm{c}_{7}, \mathrm{mtrC}$, and omcA have been identified in Desulfuromonas and Shewanella. (2) Flavin protein: ChrR, nfsA, and yieF have been found in E. coli, Pseudomonas, Gluconacetobacter, Shewanella, and Bacillus. (3) Old yellow enzymes: CrS has been discovered in Thermus scotoductus. (4) Hydrogenases: mreG and hydC have been found in Desulfovibrio [7]. The chromate reductase of Ochrobactrum sp. CUST210-1 was found at approximately $25 \mathrm{kDa}$ on the SDS-PAGE gel, suggesting that the chromate reductase was the ChrR protein; similar results were reported for S. maltophilia and Alishewanella sp. induced in the presence of $\mathrm{Cr}(\mathrm{VI})[14,40]$. To confirm this speculation, the 11 primer pairs of known chromate reductase genes were used to synthesize corresponding genes involved in $\mathrm{Cr}(\mathrm{VI})$ reduction by the CUST210-1 strain [8]. Results indicate that the chrR gene was successfully synthesized. The BLASTN analysis of the sequence indicated $99.2 \%, 97.2 \%, 96.8 \%, 94.8 \%$, 
and $92.6 \%$ similarity with the ChrR sequences from E. coli, P. putida, Shewanella sp., Gluconacetobacter sp., and S. maltophilia, respectively.

Theoretical ChrR protein sequences derived from the nucleotide sequence revealed an identical amino acid sequence for Ochrobactrum sp. CUST210-1. Figure 2 displays the crystal structure of ChrR in Ochrobactrum sp. CUST210-1. The ChrR includes three $\beta$-sheets, $14 \alpha$-helices, and five loops; BLASTP analysis revealed $98.5 \%, 96.8 \%, 95.2 \%, 91.5 \%$, and $86.8 \%$ homology to the ChrR of E. coli, P. putida, Shewanella sp., Gluconacetobacter sp., and S. maltophilia.

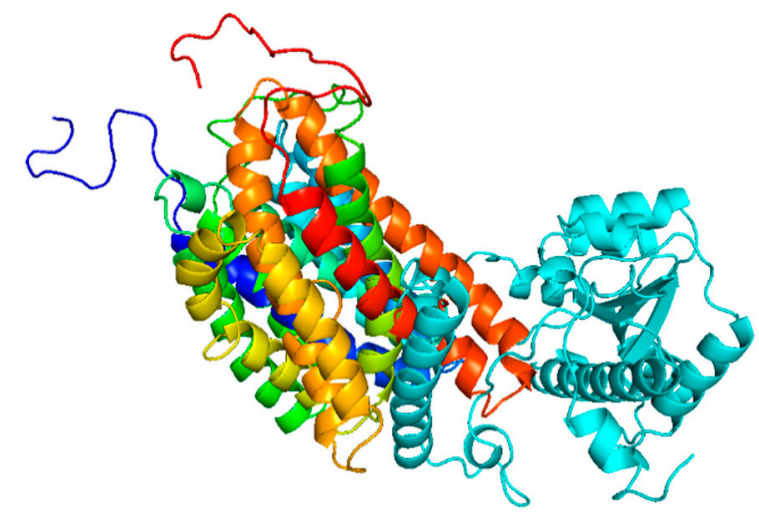

Figure 2. Crystal structure of ChrR in Ochrobactrum sp. CUST210-1.

\subsection{Toxicity Evaluation of $\mathrm{Cr}(V I)$ Reduction Products in Batch Treatment}

When 300-mg L ${ }^{-1} \mathrm{Cr}(\mathrm{VI})$-containing wastewater was treated by Ochrobactrum sp. CUST210-1 and $\mathrm{ChrR}$ in batch, $\mathrm{Cr}(\mathrm{VI})$ removal efficiencies achieved $62.5 \%$ and $48.5 \%$, respectively. The residual $\mathrm{Cr}(\mathrm{VI})$ concentrations were $112.5 \mathrm{mg} \mathrm{L}^{-1}$ with the CUST210-1 treatment and $154.2 \mathrm{mg} \mathrm{L}^{-1}$ with the ChrR treatment, respectively. Before treatment, Microtox toxicity $\left(\mathrm{EC}_{50}\right)$ and P. parva $\left(\mathrm{LC}_{50}\right)$ were $18.2-18.5 \mathrm{mg} \mathrm{L}^{-1}$ and $40.5-40.8 \mathrm{mg} \mathrm{L}^{-1}$, respectively. After treatment by the CUST210-1 strain, the toxicities of Microtox and P. parva were decreased to $62.4 \mathrm{mg} \mathrm{L}^{-1}$ and $95.8 \mathrm{mg} \mathrm{L}^{-1}$. After treatment by ChrR, the toxicities of Microtox and P. parva were decreased to $86.2 \mathrm{mg} \mathrm{L}^{-1}$ and $123.5 \mathrm{mg} \mathrm{L}^{-1}$, respectively. For Ochrobactrum sp. CUST210-1 and ChrR, respectively, 57.8-70.3\% and $67.0-78.9 \%$ detoxification efficiencies were achieved. Thus, the ChrR had higher detoxification efficiency than the bacterial cells. Notably, although the removal efficiency of the CUST210-1 strain was higher than that of ChrR protein, the reverse was true for detoxification efficiency. This may be attributed to the $\mathrm{Cr}(\mathrm{VI})$ product from the ChrR treatment being relatively simpler than that of the bacteria [5]. It also indicates the advantage and potential of the $\mathrm{Cr}(\mathrm{VI})$ treatment by $\mathrm{ChrR}$.

\subsection{Effects of Operating Parameters on Continuous Cr(VI) Removal by Immobilized Ochrobactrum sp. CUST210-1 Biosystem}

Figure 3A presents the effect of LRT on the continuous treatment of synthetic $\mathrm{Cr}(\mathrm{VI})$-containing wastewater by the immobilized Ochrobactrum sp. CUST210-1 biosystem. The results indicate that the removal efficiency for $\mathrm{Cr}(\mathrm{VI})$ gradually increased, but the removal capacity for $\mathrm{Cr}(\mathrm{VI})$ gradually decreased as the LRT increased. When the LRT was $4 \mathrm{~h}$, the removal efficiency achieved $100 \%$, and the removal capacity achieved an acceptable level of $1.71 \pm 0.2 \times 10^{-9} \mathrm{mg}-\mathrm{Cr}(\mathrm{VI})(\mathrm{cfu}-\mathrm{h})^{-1}$. Thus, the operating LRT of the experiment was set at $4 \mathrm{~h}$. Temperature and $\mathrm{pH}$ play a key role in the growth of bacterial strains; hence, their effects on the removal characteristics for $\mathrm{Cr}(\mathrm{VI})$ were evaluated. Figure $3 \mathrm{~B}$ represents the effect of $\mathrm{pH}$ on the continuous treatment of synthetic $\mathrm{Cr}(\mathrm{VI})$-containing wastewater. A pH of 7-8.5 had a nonsignificant effect $(p>0.05)$ on the removal efficiency for $\mathrm{Cr}(\mathrm{VI})$, and the removal efficiency achieved $>99.2 \% \pm 0.1 \%$. Moreover, a $\mathrm{pH}$ of $7-9$ had a nonsignificant effect $(p>0.05)$ on the removal capacity for $\mathrm{Cr}(\mathrm{VI})$, and the removal capacity was maintained in the range of $1.60 \pm 0.05$ to $1.67 \pm 0.01 \times 10^{-9} \mathrm{mg}-\mathrm{Cr}(\mathrm{VI})(\mathrm{cfu}-\mathrm{h})^{-1}$. To consider the characteristics of 
$\mathrm{Cr}(\mathrm{VI})$-containing wastewater and the operational performance of the biosystem, the $\mathrm{pH}$ value of the experiment was controlled at 7.0. An optimal $\mathrm{Cr}(\mathrm{VI})$ reduction at $\mathrm{pH} 7.0$ was determined for Bacillus sp., P. aeruginosa, and S. maltophilia $[14,36,41]$. The decrease in $\mathrm{Cr}(\mathrm{VI})$ reduction efficiency at $\mathrm{pH} 9.0$ was mainly attributed to the possibility that deviation from appropriate $\mathrm{pH}$ values may affect the degree of ionization of ChrR [36]. These results indicate the Ochrobactrum sp. CUST210-1 biosystem had good adaptability to $\mathrm{pH}$ changes. Figure $3 \mathrm{C}$ displays the effect of the operating temperature on the continuous treatment of synthetic $\mathrm{Cr}(\mathrm{VI})$-containing wastewater. An operating temperature between $30{ }^{\circ} \mathrm{C}$ and $40{ }^{\circ} \mathrm{C}$ had a nonsignificant effect $(p>0.05)$ on the removal efficiency, and an efficiency $>99.5 \%$ was achieved. By contrast, $\mathrm{Cr}(\mathrm{VI})$ reduction by Serratia rubidaea and $\mathrm{C}$. funkei was greatly influenced by temperature in a similar temperature range [35,42]. These results indicate the Ochrobactrum sp. CUST210-1 had a high adaptability to temperature changes compared with other bacterial strains. Although the removal efficiency of the biosystem achieved $99.6 \% \pm 0.08 \%$ at $40{ }^{\circ} \mathrm{C}$, the outlet $\mathrm{Cr}(\mathrm{VI})$ concentration in the effluent was $0.8 \pm 0.16 \mathrm{mg} \mathrm{L}^{-1}$-meeting the current industrial discharge standards for $\mathrm{Cr}(\mathrm{VI})$ was difficult. With a further increase of the operating temperature, $\mathrm{Cr}(\mathrm{VI})$ removal was decreased to $96.2 \% \pm 0.15 \%$, presumably due to the loss of viability or metabolic activity of the CUST210-1 strain. Thus, the operating temperature of the following experiment was controlled at $35^{\circ} \mathrm{C}$. Figure $3 \mathrm{D}$ represents the effect of the inlet $\mathrm{Cr}(\mathrm{VI})$ concentration on the continuous treatment of synthetic $\mathrm{Cr}(\mathrm{VI})$-containing wastewater. The removal capacity increased linearly with the inlet $\mathrm{Cr}(\mathrm{VI})$ concentration, indicating that the system processed a higher removal capacity, with no chromium toxicity to the CUST210-1 biosystem [36]. Moreover, the removal efficiency maintained a high efficiency until $350 \mathrm{mg} \mathrm{L}^{-1}$. Vigribacillus $\mathrm{sp}$. was reported to completely reduce $\mathrm{Cr}(\mathrm{VI})$ at $150 \mathrm{mg} \mathrm{L}^{-1}$ after $100 \mathrm{~h}$ in a batch operation [38]. Acinetobacter junii reduced 54-mg L ${ }^{-1} \mathrm{Cr}(\mathrm{VI})$ with $99.95 \%$ removal efficiency after $2 \mathrm{~h}$ in a batch operation [43]. C. funkei removed $250-\mathrm{mg} \mathrm{L}^{-1} \mathrm{Cr}(\mathrm{VI})$ with $80.43 \%$ removal efficiency after $120 \mathrm{~h}$ of exposure in a batch operation [35], whereas S. maltophilia could treat $500-\mathrm{mg} \mathrm{L}^{-1} \mathrm{Cr}(\mathrm{VI})$ with $92 \%$ removal efficiency after $120 \mathrm{~h}$ of exposure in a batch operation [14]. By comparison, Ochrobactrum sp. CUST210-1 achieved a competitive efficiency in removing $\mathrm{Cr}(\mathrm{VI})$ in a continuous operation. Although the efficiency was high at $99.5 \% \pm 0.13 \%$ when feeding with 350-mg Cr(VI) $\mathrm{L}^{-1}$, the outlet $\mathrm{Cr}(\mathrm{VI})$ concentration was $1.75 \pm 0.46 \mathrm{mg} \mathrm{L}^{-1}$, exceeding the current discharge limit of $0.5 \mathrm{mg} \mathrm{L}^{-1}$. To extend the treatment range of the $\mathrm{Cr}(\mathrm{VI})$ concentration, more details (e.g., DO control and turbidity pretreatment) for better performance were investigated by feeding with actual wastewater.

\subsection{Effects of Operating Parameters on Continuous Cr(VI) Removal by Immobilized ChrR Biosystem}

Figure $4 \mathrm{~A}$ depicts the effect of the LRT on the continuous treatment of synthetic $\mathrm{Cr}(\mathrm{VI})$-containing wastewater by the immobilized enzyme biosystem. The removal efficiency increased with the LRT, and the removal capacity decreased as the LRT increased. Optimal LRT occurred at $1 \mathrm{~h}$-at which point, the removal efficiency and capacity of the biosystem achieved $100 \%$ and $100 \pm 1.2 \mathrm{mg}-\mathrm{Cr}$ (VI) $\mathrm{L}^{-1} \mathrm{~h}^{-1}$, respectively. Thus, the operating LRT of the experiment was $1 \mathrm{~h}$. Figure $4 \mathrm{~B}$ portrays the effect of the operating temperature on the continuous treatment of synthetic $\mathrm{Cr}(\mathrm{VI})$-containing wastewater. The ChrR biosystem exhibited a high removal efficiency $(>98.20 \% \pm 0.2 \%)$ over a wide range of temperatures $\left(25^{\circ} \mathrm{C}-40{ }^{\circ} \mathrm{C}\right)$, indicating the immobilized $\mathrm{ChrR}$ had high stability in a wide temperature range. Although the efficiency of $99.65 \% \pm 0.07 \%$ at $25{ }^{\circ} \mathrm{C}$ seemed satisfactory, the outlet $\mathrm{Cr}(\mathrm{VI})$ concentration of $0.35 \pm 0.07 \mathrm{mg} \mathrm{L}^{-1}$ exceeded the maximum contaminant level of $0.05 \mathrm{mg} \mathrm{L}^{-1}$ for fisheries, drinking, ground, and surface waters. A higher temperature (e.g., $45^{\circ} \mathrm{C}$ ) could impair the function of ChrR and dramatically reduce the $\mathrm{Cr}(\mathrm{VI})$ removal efficiency [44]. Thus, the operating temperature of the experiment with the immobilized $\mathrm{ChrR}$ biosystem was controlled at $35^{\circ} \mathrm{C}$. Figure $4 \mathrm{C}$ presents the effect of the inlet $\mathrm{Cr}(\mathrm{VI})$ concentration on the continuous treatment of synthetic $\mathrm{Cr}(\mathrm{VI})$-containing wastewater. The removal efficiency was excellent $(>99.96 \%)$ at $25-150 \mathrm{mg} \mathrm{L}^{-1}$. The maximum outlet $\mathrm{Cr}(\mathrm{VI})$ concentration was only $0.045 \mathrm{mg} \mathrm{L}^{-1}$, even at $150-\mathrm{mg} \mathrm{L}^{-1} \mathrm{Cr}(\mathrm{VI})$ feeding, which meets industry effluent standards and maximum contaminant levels. Figure $4 \mathrm{D}$ displays the 
effect of the operating time on the continuous treatment of the synthetic wastewater. The removal efficiency initially maintained a high level but gradually decreased with the increased operating time. After 35 days of operation, the efficiency curve exhibited an obvious turn. On day 42, the outlet $\mathrm{Cr}(\mathrm{VI})$ concentration was $3.68 \pm 0.4 \mathrm{mg} \mathrm{L}^{-1}$, exceeding maximum contaminant levels. Thus, regular replacement (or frequency of use) during a 35-day cycle of immobilized ChrR beads should be considered to maintain high removal capabilities in a long-term operation. To our knowledge, this is first report of an immobilized ChrR biosystem applied to continuous $\mathrm{Cr}(\mathrm{VI})$ removal.

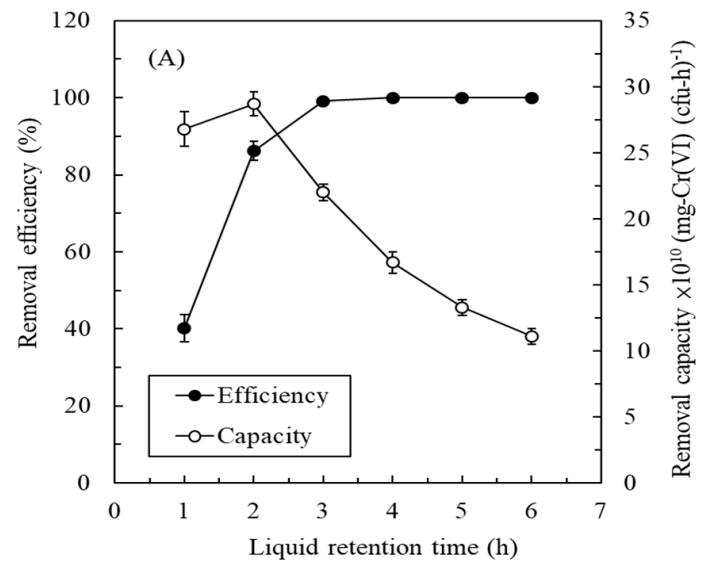

(A)

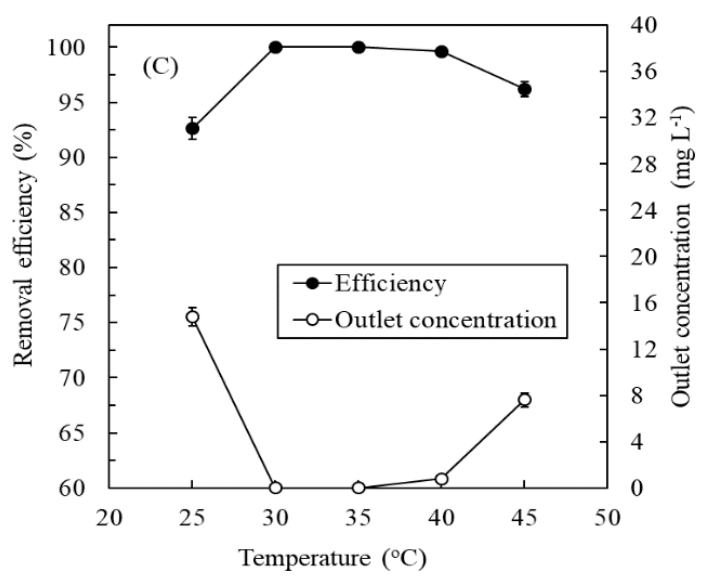

(C)

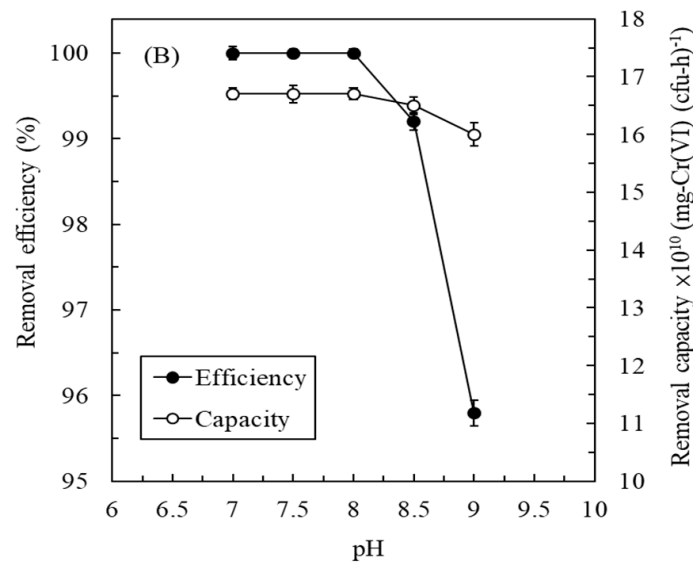

(B)

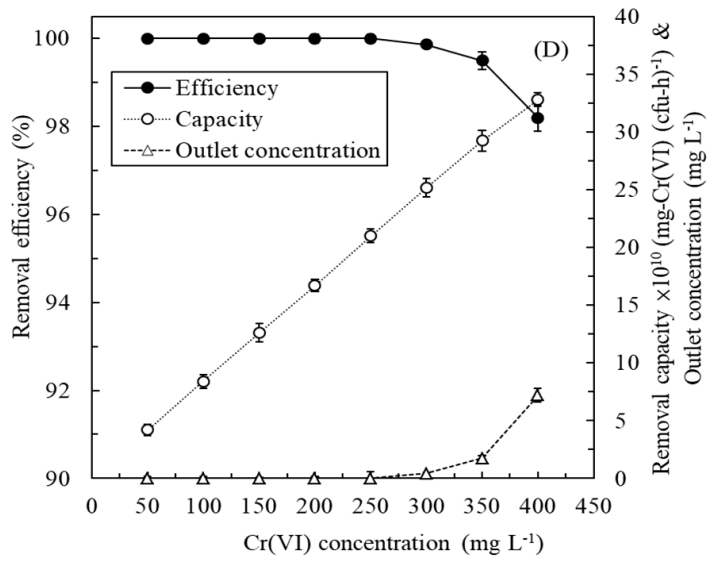

(D)

Figure 3. Effects of (A) the liquid retention time, (B) $\mathrm{pH},(\mathbf{C})$ temperature, and (D) $\mathrm{Cr}(\mathrm{VI})$ concentration on the continuous treatment of synthetic $\mathrm{Cr}(\mathrm{VI})$-containing wastewater by the immobilized Ochrobactrum sp. CUST210-1 biosystem. 


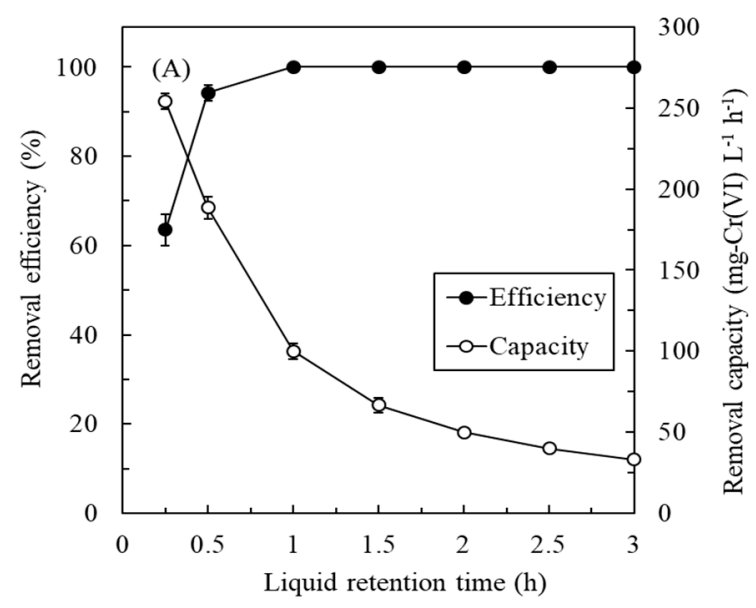

(A)

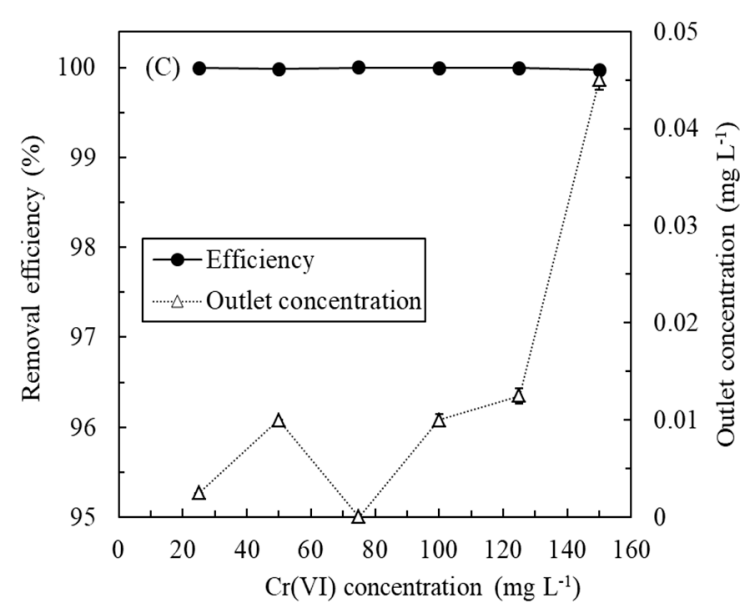

(C)

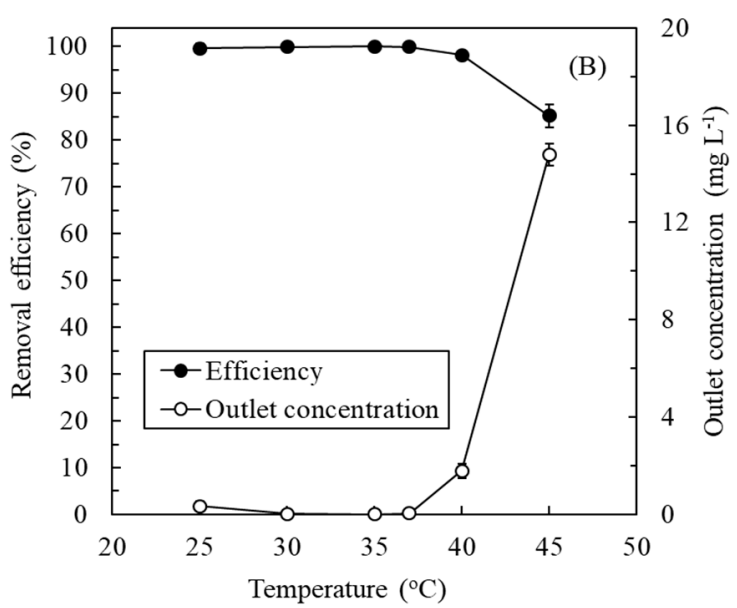

(B)

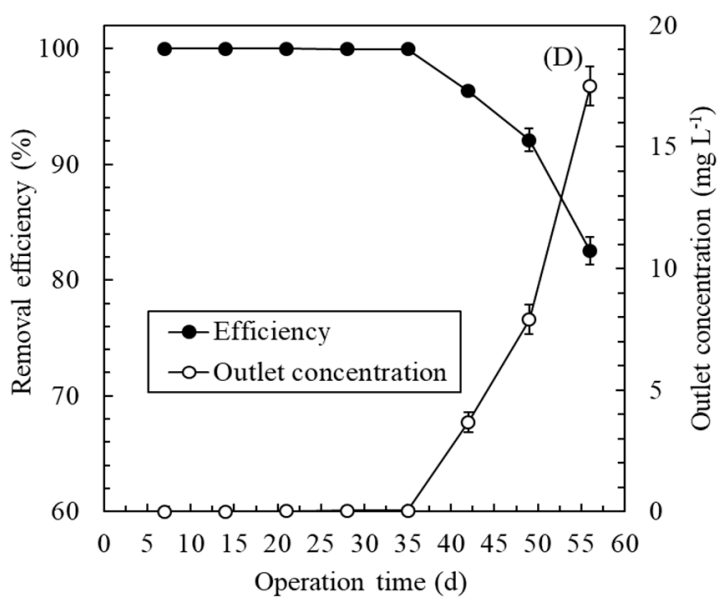

(D)

Figure 4. Effects of (A) the liquid retention time, (B) temperature, (C) $\mathrm{Cr}(\mathrm{VI})$ concentration, and (D) operation time on the continuous treatment of synthetic $\mathrm{Cr}(\mathrm{VI})$-containing wastewater by the immobilized ChrR biosystem.

3.6. Continuous Treatment of Actual Cr(VI)-Containing Wastewater by Immobilized Ochrobactrum sp. CUST210-1 Biosystem and Immobilized ChrR Biosystem

Actual Cr(VI)-containing wastewater derived from tannery or electroplating wastewater was continuously treated by our biosystems for 196 days. Average $\mathrm{S}^{2-}$ concentration, suspended solid (SS), BOD, and COD in the tannery wastewater were $2.5 \pm 0.6 \mathrm{mg} \mathrm{L}^{-1}, 303 \pm 23 \mathrm{mg} \mathrm{L}^{-1}, 158 \pm 8 \mathrm{mg} \mathrm{L}^{-1}$, and $261 \pm 15 \mathrm{mg} \mathrm{L}^{-1}$, respectively. According to the previous results, the inlet $\mathrm{pH}$ of $9.2 \pm 0.6$ was adjusted to pH $7.0 \pm 0.5$ by a pH adjustment system. Figure 5A depicts the continuous treatment of actual tannery wastewater by the immobilized Ochrobactrum sp. CUST210-1 biosystem. The inlet $\mathrm{Cr}(\mathrm{VI})$ concentration varied from 284 to $471 \mathrm{mg} \mathrm{L}^{-1}$ during the 196-day treatment period. The change of luminescent $V$. fischeri toxicity (luminescence inhibition) in response to the water quality and the dynamic of the outlet $\mathrm{Cr}(\mathrm{VI})$ concentration were similar. This suggested that the residual $\mathrm{Cr}(\mathrm{VI})$ concentration was associated with the toxicity of the wastewater. The outlet $\mathrm{Cr}(\mathrm{VI})$ concentration exceeded the discharge limit of $0.5 \mathrm{mg} \mathrm{L}^{-1}$ on day 14 , day 56, day 63, day 91, day 154, day 189, and day 196. Although the inlet concentration was only $295 \pm 1.7 \mathrm{mg} \mathrm{L}^{-1}$ (below the ideal treatment concentration, $300 \mathrm{mg} \mathrm{L}^{-1}$ ) on day 91 , the removal efficiency dropped to $98.52 \% \pm 0.04 \%$, with an outlet concentration of $4.37 \pm 0.09 \mathrm{mg} \mathrm{L}^{-1}$ due to turbidity problems. When a filter device was installed, even with an inlet concentration as 
high as $425 \pm 10 \mathrm{mg} \mathrm{L}^{-1}$ (on day 133), the removal efficiency achieved $99.91 \% \pm 0.04 \%$, with an outlet concentration of $0.38 \pm 0.17 \mathrm{mg} \mathrm{L}^{-1}$. When $408 \pm 3.75-\mathrm{mg} \mathrm{L}^{-1} \mathrm{Cr}(\mathrm{VI})$ was introduced to the biosystem on day 154 , the removal efficiency dropped to $97.86 \% \pm 0.27 \%$, with an outlet concentration of $8.73 \pm 1.16 \mathrm{mg} \mathrm{L}^{-1}$ because of an insufficient DO supply $\left(3.6 \pm 0.4 \mathrm{mg} \mathrm{L}^{-1}\right)$. Thus, an aeration device and a DO sensor were installed (DO would be controlled at $>4.0 \mathrm{mg} \mathrm{L}^{-1}$ ), and the removal efficiency gradually rose and stabilized. With the filter device, aeration device, and $\mathrm{DO}$ sensor, the outlet $\mathrm{Cr}(\mathrm{VI})$ concentration would meet the industry discharge limit of $0.5 \mathrm{mg} \mathrm{L}^{-1}$ if the inlet $\mathrm{Cr}(\mathrm{VI})$ concentration was below $430 \mathrm{mg} \mathrm{L}^{-1}$.

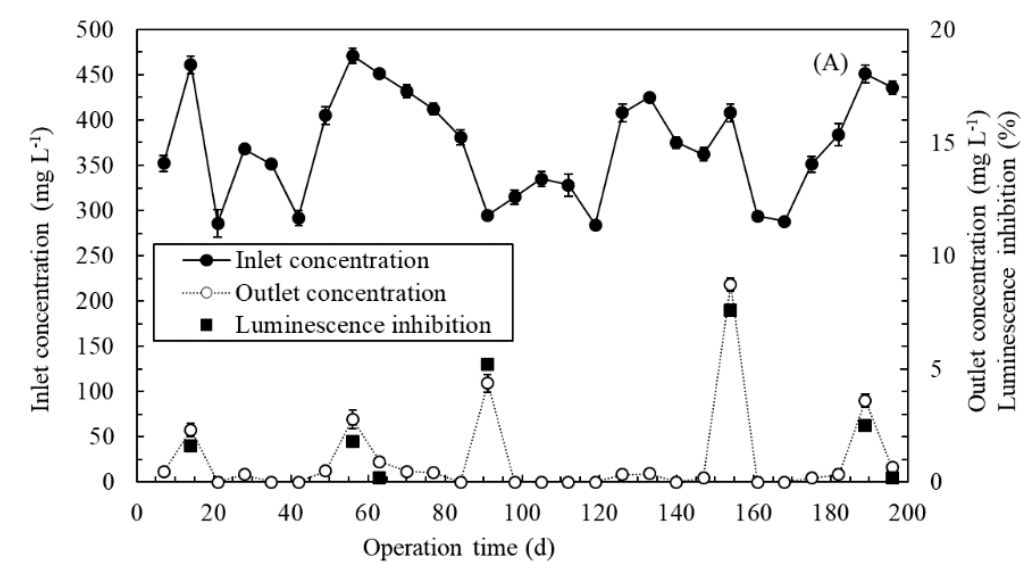

(a)

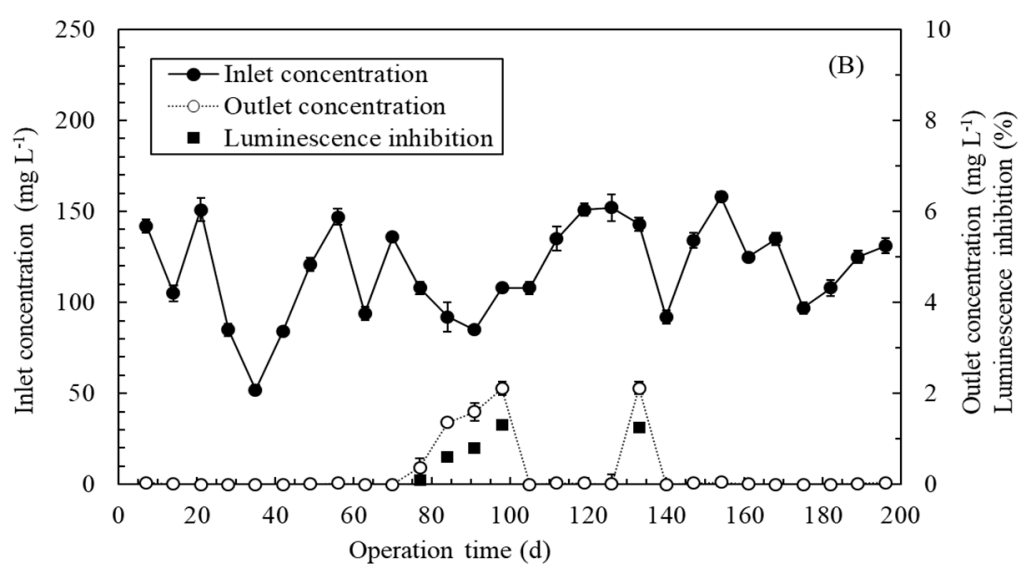

(b)

Figure 5. Continuous treatment of actual $\mathrm{Cr}(\mathrm{VI})$-containing wastewater by (a) the immobilized Ochrobactrum sp. CUST210-1 biosystem and (b) immobilized ChrR biosystem.

Figure $5 \mathrm{~B}$ represents the continuous treatment of actual electroplating wastewater by the immobilized ChrR biosystem. The average $\mathrm{Ni}^{+}$concentration, $\mathrm{Na}^{+}$concentration, $\mathrm{SO}_{4}{ }^{2-}$ concentration, $\mathrm{Cl}^{-}$concentration, $\mathrm{SS}, \mathrm{BOD}$, and COD in the wastewater were $13.5 \pm 0.6 \mathrm{mg} \mathrm{L}^{-1}, 4.2 \pm 0.8 \mathrm{mg} \mathrm{L}^{-1}$, $6.5 \pm 0.7 \mathrm{mg} \mathrm{L}^{-1}, 4.8 \pm 0.3 \mathrm{mg} \mathrm{L}^{-1}, 24 \pm 2.3 \mathrm{mg} \mathrm{L}^{-1}, 42 \pm 5.6 \mathrm{mg} \mathrm{L}^{-1}$, and $68 \pm 2.7 \mathrm{mg} \mathrm{L}^{-1}$, respectively. According to the previous results, a $\mathrm{pH}$ adjustment system was installed to adjust the $\mathrm{pH}$ of the water from $5.1 \pm 0.8$ to $7.0 \pm 0.5$. The inlet $\mathrm{Cr}(\mathrm{VI})$ concentration varied from 52 to $158 \mathrm{mg} \mathrm{L}^{-1}$ during the 196-day treatment period. The trend between the changes in the luminescent bacteria toxicity for water quality and the dynamics of the outlet $\mathrm{Cr}(\mathrm{VI})$ concentration was consistent. To evaluate the adaptability of the biosystem, the immobilized enzyme replacement was deliberately neglected on the 
70th day, because the replacement frequency was set to a 35-day cycle. The outlet $\mathrm{Cr}(\mathrm{VI})$ concentration exceeded the maximum contaminant level of $0.05 \mathrm{mg} \mathrm{L}^{-1}$ on days $77-98$. On day 105, the immobilized ChrR beads were replaced, and the removal efficiency gradually stabilized to $>99.97 \%$. Moreover, the outlet concentration was less than $0.05 \mathrm{mg} \mathrm{L}^{-1}$. When $143 \pm 0.65-\mathrm{mg} \mathrm{L}^{-1} \mathrm{Cr}(\mathrm{VI})$ was fed on day 133, the removal efficiency dropped to $98.52 \% \pm 0.05 \%$, with an outlet concentration of $2.11 \pm 0.08 \mathrm{mg} \mathrm{L}^{-1}$ because of an insufficient DO supply $\left(2.8 \pm 0.6 \mathrm{mg} \mathrm{L}^{-1}\right)$. Thus, an aeration device and a DO sensor were installed, and DO in the wastewater was controlled at $>3.0 \mathrm{mg} \mathrm{L}^{-1}$. The removal efficiency of the immobilized ChrR biosystem gradually stabilized at $99.98-100 \%$, and the outlet $\mathrm{Cr}(\mathrm{VI})$ concentration conformed to the maximum contaminant level of $0.05 \mathrm{mg} \mathrm{L}^{-1}$. Although the maximum contaminant standards for waterbody and wastewater discharges differ at present, developing effective technology to meet future, more stringent standards is worthwhile.

In the literature, limited studies have focused on the treatment of actual $\mathrm{Cr}(\mathrm{VI})$-containing wastewater by a continuous biosystem. Rida et al. (2012) utilized an immobilized O. intermedium batch system to remove 268 - $\mathrm{mg} \mathrm{L}^{-1} \mathrm{Cr}(\mathrm{VI})$ from artificial and industrial sewage waters and achieved $65 \%$ and $91.2 \%$ removal efficiencies, respectively, within $72 \mathrm{~h}$ [45]. Chen et al. (2016) applied a microbial fuel cell to remove $300-\mathrm{mg} \mathrm{L}^{-1} \mathrm{Cr}(\mathrm{VI})$ from synthetic wastewater under anaerobic conditions and achieved a 96.5\% removal efficiency [11]. Jin et al. (2017) utilized a sequencing batch reactor to remove 80-mg L ${ }^{-1} \mathrm{Cr}(\mathrm{VI})$ from synthetic wastewater and achieved an $81.3 \%$ removal efficiency [4]. Our immobilized Ochrobactrum sp. CUST210-1 and immobilized ChrR biosystems substantially reduced the $\mathrm{Cr}(\mathrm{VI})$ concentrations of $<425 \mathrm{mg} \mathrm{L}^{-1}$ and $<150 \mathrm{mg} \mathrm{L}^{-1}$, respectively, in actual $\mathrm{Cr}$ (VI)-containing wastewater, suggesting that these developed biosystems can be used in the bioremediation of various $\mathrm{Cr}(\mathrm{VI})$-contaminated wastewaters.

\subsection{Characteristics and Economic Analysis of the Biosystems}

In designing a feasible biosystem, the main goal is to meet a performance level and minimize capital and operating costs. Table 4 offers a comparison of economic and operational characteristics of the biological system and the enzyme system. The basis of the evaluation was to scale up the infrastructure of the reactor system by 10 for field applications. The treatment cost was estimated per one-year cost, and related infrastructures, including the reactor itself, piping, filter device, and aeration device, were calculated based on 10-year life amortizations. The electricity cost was calculated at $\$ 25$ per month. The results indicate the total costs of the immobilized Ochrobactrum sp. CUST210-1 biosystem $\left(\$ 6750 \mathrm{y}^{-1}\right)$ were higher than those of the immobilized ChrR biosystem $\left(\$ 6050 \mathrm{y}^{-1}\right)$. This is due in part to the CUST210-1 biosystem's requirement of a filter device to remove suspended solids from tannery wastewater. The biological treatment system can be applied to treat wastewater with high concentrations of $\mathrm{Cr}(\mathrm{VI})\left(\sim 425 \mathrm{mg} \mathrm{L}^{-1}\right)$, and the effluent can comply with industrial wastewater discharge standards $\left(<0.5 \mathrm{mg} \mathrm{L}^{-1}\right)$. The biological treatment system required a long LRT, and thus, the allowable inflow rate was low (Table 5). In addition, a filter device and DO monitoring were required to improve the removal performance during the operating period. By contrast, the immobilized enzyme system was suitable for treating diluted $\mathrm{Cr}(\mathrm{VI})$-containing wastewater $\left(\sim 150 \mathrm{mg} \mathrm{L}^{-1}\right)$, and the effluent could comply with strict water quality standards and meet the standards for fisheries and drinking water $\left(<0.05 \mathrm{mg} \mathrm{L}^{-1}\right)$. The ChrR biosystem also operated at a short LRT, and thus, the allowable inflow rate was high. However, DO monitoring and regular replacement of ChrR beads were required to improve performance during the operating period. To date, this is the first report to compare the economic and operational characteristics of biosystems for $\mathrm{Cr}(\mathrm{VI})$ removal. 
Table 4. Comparison of economic and operational characteristics between the immobilized Ochrobactrum sp. CUST210-1 biosystem and immobilized ChrR biosystem. BOD: Biochemical oxygen demand.

\begin{tabular}{|c|c|c|c|c|c|}
\hline & $\begin{array}{l}\text { Bacterial Culture } \\
\text { (USD/y) }\end{array}$ & $\begin{array}{l}\text { Enzyme Extraction \& } \\
\text { Immobilization (USD/y) }\end{array}$ & $\begin{array}{l}\text { Reactor Installation } \\
\text { (USD/y) }\end{array}$ & $\begin{array}{c}\text { Operational Costs } \\
{ }_{1} \text { (USD/y) }\end{array}$ & Application Scope \\
\hline CUST210-1 & 350 & - & $6000^{2}$ & 400 & $\begin{array}{l}\text { (1) BOD > } 150 \mathrm{mg} \mathrm{L}^{-1} \\
\text { (2) Inlet Cr(VI) conc: } \\
\text { 250-425 mg L } \\
\text { (3) Outlet Cr(VI) conc: } \\
<0.5 \mathrm{mg} \mathrm{L}^{-1}\end{array}$ \\
\hline ChrR & 350 & $350^{3}$ & 5000 & 350 & $\begin{array}{l}\text { (1) } \mathrm{BOD}<50 \mathrm{mg} \mathrm{L}^{-1} \\
\text { (2) Inlet } \mathrm{Cr}(\mathrm{VI}) \text { conc: } \\
\text { 50-150 mg L } \\
\text { (3) Outlet } \mathrm{Cr}(\mathrm{VI}) \text { conc: } \\
<0.05 \mathrm{mg} \mathrm{L}^{-1}\end{array}$ \\
\hline
\end{tabular}

${ }^{1}$ Operating costs include electricity consumption, $\mathrm{pH}$ adjustment, filter material, and other miscellaneous costs. ${ }^{2}$ Includes filter device. ${ }^{3}$ Bead replacement $\left(10\right.$ times $\left.\mathrm{y}^{-1}\right)$.

Table 5. Comparison of economic and operational characteristics between the immobilized Ochrobactrum sp. CUST210-1 biosystem and immobilized ChrR biosystem. DO: dissolved oxygen.

\begin{tabular}{lccl}
\hline & $\begin{array}{c}\text { Manpower Requirement \& } \\
\text { Ease of Operation }\end{array}$ & $\begin{array}{l}\text { Frequency of Sludge } \\
\left.\text { Treatment (time } \mathbf{y}^{-1}\right)\end{array}$ & \multicolumn{1}{c}{ Characteristics } \\
\hline CUST210-1 & 1 & $\begin{array}{l}\text { (1) Suitable for treating high Cr(VI) conc. and } \\
\text { complying with wastewater discharge standard } \\
\text { (2) Suitable for low influent flow rate } \\
\text { (3) Requires filter device and DO monitor }\end{array}$ \\
\hline ChrR & Relatively high & 10 & $\begin{array}{l}\text { (1) Suitable for treating low Cr(VI) conc. and } \\
\text { complying with stricter environmental standards } \\
\text { (2) Allows high influent flow rate } \\
\text { (3) Requires DO monitor and regular replacement } \\
\text { of enzyme beads }\end{array}$ \\
\hline
\end{tabular}

\section{Conclusions}

The results clearly demonstrate the application potential of an immobilized Ochrobactrum sp. CUST210-1 biosystem and an immobilized ChrR biosystem. The Ochrobactrum sp. CUST210-1 biosystem demonstrated good adaptability to $\mathrm{pH}$ variation and was able to operate at a long LRT with relatively concentrated $\mathrm{Cr}(\mathrm{VI})$, but it had a relatively high cost. The chrR gene was identified in Ochrobactrum sp. CUST210-1; thus, the ChrR protein is responsible for $\mathrm{Cr}(\mathrm{VI})$ reduction and results in large amounts of $\mathrm{Cr}(\mathrm{OH})_{3(\mathrm{~s})}$. The ChrR biosystem exhibited good adaptability to the operating temperature and was able to operate at a short LRT with relatively diluted concentrations, and it was relatively cheap. The Ochrobactrum sp. CUST210-1 biosystem is recommended for tannery wastewater treatment, especially for a posttreatment system. The immobilized ChrR biosystem is recommended for electroplating wastewater treatment as a posttreatment system or in preparation for meeting stricter water quality standards in the future. Through economic analysis and a comparison of operation characteristics, we provided insight into strategies for removing $\mathrm{Cr}(\mathrm{VI})$ from various environments.

Author Contributions: All authors collaborated to carry out the work presented here. Y.-C.C. and G.-H.W. conceived and designed the experiments; T.-H.T., C.-H.C., and C.-Y.C. performed the experiments; Y.-C.C. wrote the paper; and T.-H.T., G.-H.W., and Y.-C.C. reviewed and edited the manuscript. All authors have read and agreed to the published version of the manuscript.

Funding: This research was supported by the Ministry of Science and Technology of Taiwan, grant numbers MOST 107-2313-B-157-001-MY2 and MOST 109-2313-B-157-001.

Acknowledgments: We thank Chen, P.Y., Chou, K.W., Hsu, H.J., and Chen, C.Y. for helping with partial paperwork and data processing. This manuscript was edited by Wallace Academic Editing.

Conflicts of Interest: The authors declare no conflict of interest. 


\section{References}

1. Viti, C.; Marchi, E.; Decorosi, F.; Giovannetti, L. Molecular mechanisms of Cr(VI) resistance in bacteria and fungi. FEMS Microbiol. Rev. 2014, 38, 633-659. [CrossRef] [PubMed]

2. Cervantes, C.; Campos-Garcia, J.; Devars, S.; Gutierrez-Corona, F.; Loza-Tavera, H.; Torres-Guzman, J.C.; Moreno-Sánchez, R. Interactions of chromium with microorganisms and plants. FEMS Microbiol. Rev. 2001, 25, 335-347. [CrossRef] [PubMed]

3. Avudainayagam, S.; Megharaj, M.; Owens, G.; Kookana, R.S.; Chittleborough, D.; Naidu, R. Chemistry of chromium in soils with emphasis on tannery waste sites. Rev. Environ. Contam. Toxicol. 2003, 178, 53-91.

4. Jin, R.; Liu, Y.; Liu, G.; Tian, T.; Qiao, S.; Zhou, J. Characterization of Product and potential mechanism of $\mathrm{Cr}(\mathrm{VI})$ reduction by anaerobic activated sludge in a sequencing batch reactor. Sci. Rep. 2017, 7, 1681. [CrossRef] [PubMed]

5. Jobby, R.; Jha, P.; Yadav, A.K.; Desai, N. Biosorption and biotransformation of hexavalent chromium [Cr(VI)]: A comprehensive review. Chemosphere 2018, 207, 255-266. [CrossRef]

6. Rahman, A.; Nahar, N.; Nawani, N.N.; Jass, J.; Hossain, K.; Saud, Z.A.; Saha, A.K.; Ghosh, S.; Olsson, B.; Mandal, A. Bioremediation of hexavalent chromium (VI) by a soil-borne bacterium, Enterobacter cloacae B2-DHA. J. Environ. Sci. Health A 2015, 50, 1136-1147. [CrossRef]

7. Joutey, N.T.; Sayel, H.; Bahafid, W.; El Ghachtouli, N. Mechanisms of hexavalent chromium resistance and removal by microorganisms. Rev. Environ. Contam. Toxicol. 2015, 233, 45-69.

8. Thatoi, H.; Das, S.; Mishra, J.; Rath, B.P.; Das, N. Bacterial chromate reductase, a potential enzyme for bioremediation of hexavalent chromium: A review. J. Environ. Manag. 2014, 146, 383-399. [CrossRef]

9. Somasundaram, V.; Philip, L.; Bhallamudi, S.M. Experimental and mathematical modeling studies on Cr(VI) reduction by CRB, SRB and IRB, individually and in combination. J. Hazard. Mater. 2009, 172, $606-617$. [CrossRef]

10. Srivastava, N.; Dhal, B.; Abhilash; Pandey, B.D. Bioreduction of hexavalent chromium by Bacillus cereus isolated from chromite mine overburden soil. Adv. Mater. Res. 2013, 828, 81-91. [CrossRef]

11. Chen, C.Y.; Cheng, C.Y.; Chen, C.K.; Hsieh, M.C.; Lin, S.T.; Ho, K.Y.; Li, J.W.; Lin, C.P.; Chung, Y.C. Hexavalent chromium removal and bioelectricity generation by Ochrobactrum sp. YC211 under different oxygen conditions. J. Environ. Sci. Health A 2016, 51, 502-508. [CrossRef] [PubMed]

12. Li, J.; Guo, W.; Shi, M.; Cao, Y.; Wang, G. High-quality-draft genomic sequence of Paenibacillus ferrarius CY1 T with the potential to bioremediate Cd, Cr and Se contamination. Stand Genomic Sci. 2017, 12, 60. [CrossRef] [PubMed]

13. Wu, L.C.; Wang, G.H.; Tsai, T.H.; Lo, S.Y.; Cheng, C.Y.; Chung, Y.C. Three-stage single-chambered microbial fuel cell biosensor inoculated with Exiguobacterium aestuarii YC211 for continuous chromium (VI) measurement. Sensors 2019, 19, 1418.

14. Baldiris, R.; Acosta-Tapia, N.; Montes, A.; Hernández, J.; Vivas-Reyes, R. Reduction of hexavalent chromium and detection of chromate reductase (ChrR) in Stenotrophomonas maltophilia. Molecules 2018, 23, 406. [CrossRef]

15. Murugavelh, S.; Mohanty, K. Bioreduction of chromate by immobilized cells of Halomonas sp. Int. J. Energy Environ. 2013, 4, 349-356.

16. Robins, K.J.; Hooks, D.O.; Rehm, B.H.A.; Ackerley, D.F. Escherichia coli NemA is an efficient chromate reductase that can be biologically immobilized to provide a cell free system for remediation of hexavalent chromium. PLoS ONE 2013, 8, e59200. [CrossRef]

17. American Public Health Association. Method 8050 Liquid-Phase Toxicity Test Using Luminescent Bacteria Vibrio Fischeri, Standard Methods for the Examination of Water and Wastewater, 21st ed.; Part 8050; American Public Health Association, American Water Works Association, Water Environment Federation: Washington, DC, USA, 2005.

18. American Public Health Association. Standard Methods for the Examination of Water and Wastewater, 22nd ed.; Part 8000; American Public Health Association, American Water Works Association, Water Environment Federation: Washington, DC, USA, 2012.

19. Lake, D.L.; Kirk, P.W.W.; Lester, J.N. The effects of anaerobic-digestion on heavy-metal distribution in sewage sludge. Water Pollut. Control 1985, 84, 549.

20. Vyrides, I.; Stuckey, D.C. Chromium removal mechanisms and bacterial community in an integrated membrane bioreactor system. Environ. Eng. Sci. 2011, 28, 661-670. [CrossRef] 
21. Laemmli, U.K. Cleavage of structural proteins during the assembly of the head of bacteriophage T4. Nature 1970, 227, 680-685. [CrossRef]

22. Jin, H.; Zhang, Y.; Buchko, G.W.; Varnum, S.M.; Robinson, H.; Squier, T.C.; Long, P.E. Structure determination and functional analysis of a chromate reductase from Gluconacetobacter hansenii. PLoS ONE 2012, 7, e42432. [CrossRef] [PubMed]

23. Ackerley, D.F.; Gonzalez, C.F.; Park, C.H.; Blake, R.; Keyhan, M.; Matin, A. Chromate-reducing properties of soluble flavoproteins from Pseudomonas putida and Escherichia coli. Appl. Environ. Microbiol. 2004, 70, 873-882. [CrossRef] [PubMed]

24. Ackerley, D.F.; Gonzalez, C.F.; Keyhan, M.; Blake, R.; Matin, A. Mechanism of chromate reduction by the Escherichia coli protein, NfsA, and the role of different chromate reductases in minimizing oxidative stress during chromate reduction. Environ. Microbiol. 2004, 6, 851-860. [CrossRef] [PubMed]

25. Kwak, Y.H.; Lee, D.S.; Kim, H.B. Vibrio harveyi nitroreductase is also a chromate reductase. Appl. Environ. Microbiol. 2003, 69, 4390-4395. [CrossRef] [PubMed]

26. Mugerfeld, I.; Law, B.A.; Wickham, G.S.; Thompson, D.K. A putative azoreductase gene is involved in the Shewanella oneidensis response to heavy metal stress. Appl. Microbiol. Biotechnol. 2009, 82, 1131-1141. [CrossRef] [PubMed]

27. Li, X.; Krumholz, L.R. Thioredoxin is involved in U(VI) and $\mathrm{Cr}(\mathrm{VI})$ reduction in Desulfovibrio desulfuricans G20. J. Bacteriol. 2009, 191, 4924-4933. [CrossRef] [PubMed]

28. Michel, C.; Brugna, M.; Aubert, C.; Bernadac, A.; Bruschi, M. Enzymatic reduction of chromate: Comparative studies using sulfate-reducing bacteria. Key role of polyheme cytochromes c and hydrogenases. Appl. Microbiol. Biotechnol. 2001, 55, 95-100. [CrossRef]

29. Magnuson, T.S.; Swenson, M.W.; Paszczynski, A.J.; Deobald, L.A.; Kerk, D.; Cummings, D.E. Proteogenomic and functional analysis of chromate reduction in Acidiphilium cryptum JF-5, an Fe(III)-respiring acidophile. BioMetals 2010, 23, 1129-1138. [CrossRef]

30. Belchik, S.M.; Kennedy, D.W.; Dohnalkova, A.C.; Wang, Y.; Sevinc, P.C.; Wu, H.; Lin, Y.; Lu, H.P.; Fredrickson, J.K.; Shi, L. Extracellular reduction of hexavalent chromium by cytochromes MtrC and OmcA of Shewanella oneidensis MR-1. Appl. Environ. Microbiol. 2011, 77, 4035-4041. [CrossRef]

31. De Silva, B.C.J.; Hossain, S.; Dahanayake, P.S.; Heo, G.J. Frozen white-Leg shrimp (Litopenaeus vannamei) in korean markets as a source of Aeromonas spp. harboring antibiotic and heavy metal resistance genes. Microb. Drug Resist. 2018, 24, 1587-1598. [CrossRef]

32. Riaz, A.; Qader, S.A.; Anwar, A.; Iqbal, S. Immobilization of a thermostable $\alpha$-amylase on calcium alginate beads from Bacillus subtilis KIBGE-HAR. Aus. J. Basic Appl. Sci. 2009, 3, 2883-2887.

33. Das, S.; Mishra, J.; Das, S.K.; Pandey, S.; Rao, D.S.; Chakraborty, A.; Sudarshan, M.; Das, N.; Thatoi, H. Investigation on mechanism of $\mathrm{Cr}(\mathrm{VI})$ reduction and removal by Bacillus amyloliquefaciens, a novel chromate tolerant bacterium isolated from chromite mine soil. Chemosphere 2014, 96, 112-121. [CrossRef] [PubMed]

34. Khattar, J.I.S.; Parveen, S.; Singh, Y.; Singh, D.P.; Gulati, A. Intracellular uptake and reduction of hexavalent chromium by the cyanobacterium Synechocystis sp. PUPCCC 62. J. Appl. Phycol. 2015, 27, 827-837. [CrossRef]

35. Karthik, C.; Ramkumar, V.S.; Pugazhendhi, A.; Gopalakrishnan, K.; Arulselvi, P.I. Biosorption and biotransformation of $\mathrm{Cr}(\mathrm{VI})$ by novel Cellulosimicrobium funkei strain AR6. J. Taiwan Inst. Chem. Eng. 2016, 70, 282-290. [CrossRef]

36. Kang, C.; Wu, P.; Li, L.; Yu, L.; Ruan, B.; Gong, B.; Zhu, N. Cr(VI) reduction and Cr(III) immobilization by resting cells of Pseudomonas aeruginosa CCTCC AB93066: Spectroscopic, microscopic, and mass balance analysis. Environ. Sci. Pollut. Res. Int. 2017, 24, 5949-5963. [CrossRef]

37. Cheng, Y.; Yan, F.; Huang, F.; Chu, W.; Pan, D.; Chen, Z.; Zheng, J.; Yu, M.; Lin, Z.; Wu, Z. Bioremediation of $\mathrm{Cr}(\mathrm{VI})$ and immobilization as $\mathrm{Cr}(\mathrm{III})$ by Ochrobactrum anthropic. Environ. Sci. Technol. 2010, 44, 6357-6363. [CrossRef] [PubMed]

38. Mishra, R.R.; Dhal, B.; Dutta, S.K.; Dangar, T.K.; Das, N.N.; Thatoi, H.N. Optimization and characterization of chromium(VI) reduction in saline condition by moderately halophilic Vigribacillus sp. isolated from mangrove soil of Bhitarkanika. India. J. Hazard. Mater. 2012, 227-228, 219-226. [CrossRef]

39. Mohamed, A.; Yu, L.; Fang, Y.; Ashry, N.; Riahi, Y.; Uddin, I.; Dai, K.; Huang, Q. Iron mineral-humic acid complex enhanced $\mathrm{Cr}(\mathrm{VI})$ reduction by Shewanella oneidensis MR-1. Chemosphere 2020, 247. in press. [CrossRef] 
40. Xia, X.; Wu, S.; Li, N.; Wang, D.; Zheng, S.; Wang, G. Novel bacterial selenite reductase CsrF responsible for Se (IV) and Cr (VI) reduction that produces nanoparticles in Alishewanella sp. WH16-1. J. Hazard. Mater. 2018, 342, 499-509. [CrossRef]

41. Dhal, B.; Thatoi, H.N.; Das, N.N.; Pandey, B.D. Reduction of hexavalent chromium by Bacillus sp. isolated from chromite mine soils and characterization of reduced product. J. Chem. Technol. Biotechnol. 2010, 85, 1471-1479. [CrossRef]

42. Hirpara, P.; Nikhil, B.; Murty, D.S. Bacterial treatment for removal of chromium (VI) containing electroplating waste waters. Indian J. Appl. Res. 2014, 4, 436-438. [CrossRef]

43. Mrudula, P.; Jamwal, S.; Samuel, J.; Chandrasekaran, N.; Mukherjee, A. Enhancing the hexavalent chromium bioremediation potential of Acinetobacter junii VITSUKMW2 using statistical design experiments. J. Microbiol. Biotechnol. 2012, 22, 1767-1775.

44. Xu, F.; Ma, T.; Shi, L.; Zhang, J.W. Bioreduction of $\mathrm{Cr}(\mathrm{VI})$ by Bacillus sp. QH-1 isolated from soil under chromium-containing slag heap in high altitude area. Ann. Microbiol. 2013, 64, 1073-1080. [CrossRef]

45. Rida, B.; Yrjälä, K.; Hasnain, S. Hexavalent chromium reduction by bacteria from tannery effluent. J. Microbiol. Biotechnol. 2012, 22, 547-554.

(C) 2020 by the authors. Licensee MDPI, Basel, Switzerland. This article is an open access article distributed under the terms and conditions of the Creative Commons Attribution (CC BY) license (http://creativecommons.org/licenses/by/4.0/). 